\section{New Cooling System for Aero-Engines}

Messrs. Rolls Royce have introduced a new system of water cooling under pressure on their "Merlin IV" engine. This is similar to the usual atmospheric one, but is closed and provided with loaded valves, so that the boiling point of the water under pressure is raised. The many recent developments in metallurgy and lubricating oils have made it possible for the internal combustion engine to function at higher temperatures, and thus to increase thermal efficiency, in addition to the obvious advantage of using smaller radiators with both less drag and weight. The more general method up to the present of maintaining the engine at the higher temperature permissible has been to use liquids with higher boiling points. Ethylene glycol is the most generally used in Great Britain, but this has objections in its corrosive effect upon parts of the cooling system, especially the inevitable joints, if a substance such as a rubber or leather compound is used. Extra cost, and the necessity of carrying a supply of the special liquid, are also points against such preparations. The new radiator and cooling system fittings may need to be somewhat more robust for dealing with pressure, but this is not altogether a disadvantage in that the more solid construction will add to its reliability. Weakness due to flimsy construction has often been typical of the older water cooling systems. It is reported that these engines with their new cooling will be fitted to the Armstrong Whitworth "Whitley" the new R.A.F. bomber, now coming into production.

\section{British Speleological Association}

AT the third annual conference of the British Speleological Association, which opened at Giggleswick School, Yorks, on July 30, Dr. R. R. Marett, rector of Exeter College, Oxford, was elected president in succession to Sir Arthur Keith, who has held that office since the foundation of the Association. As an anthropologist Dr. Marett is perhaps best known for his studies of the religion and psychology of primitive peoples, but his connexion with the archæological exploration of caves is of long standing. In 1911 he described before Section $H$ of the British Association the excavations in the cave in St. Brelade's Bay, Jersey, carried out by himself and other members of the Société Jersiaise, which resulted in the important discovery of a tooth of Neanderthal man in association with Mousterian implements.

THE conference of the Speleological Association was declared open in an original and appropriate ceremonial by Mr. J. A. Slingsby, chairman of the Governors of Giggleswick School. At a business meeting of the Association it was reported that the survey of underground waters in Yorkshire, Derbyshire and Somersetshire is being continued, and that considerable progress had been made in listing the caves of Britain in which archæological material had been found in the past. In addition to papers presented for discussion at sectional meetings, the proceedings included visits to a number of museums in
Settle and neighbourhood containing material illustrating and recording the results of cave exploration, and visits to the caves themselves, including the Victoria and Jubilee caves, long well known for their archæological importance, and Gaping Ghyll on Ingleborough, with its $340 \mathrm{ft}$. shaft, miles of passages and huge main chamber. On the evening of August 1, Sir Arthur Smith Woodward addressed the Association on "Wild Animals Living with Early Man in Britain". The Association will meet next year at Swansea.

\section{Roman Site in Wiltshire}

AN impressive indication of the general diffusion of a high degree of refinement in mode of life in Roman Britain, and also of the economic and social decadence which accompanied the decay of Roman rule, is afforded by the remains of a villa recently discovered at Atworth in Wiltshire (The Times, August 6). It is indeed remarkable that traces of a building of such an extent as has been revealed in the excavations of 1937-38 should have evaded previous record. Its existence was made known only through the discovery by a schoolboy in a cornfield of a coin afterwards identified as of Constantine $I$. This led to an investigation, which was begun in August 1937 and at once revealed courses of masonry, in some instances no more than six inches below the ploughed surface, now known to have been part of an L-shaped house of 'corridor' type, containing at least twenty-four rooms or passages, a suite of baths, four or possibly five hypocaust chambers, a flight of six stone steps, and three rather inferior tesselated floors. Evidence that either on this site, or in the immediate neighbourhood, there had stood a building of considerable architectural pretensions was found in the form of fragments of stone used to support a floor in one of the hypocausts, which were well worked and showed good mouldings. They had once formed part of a cornice or plinth of a building in classic style. The house was roofed with purplish pointed tiles of sandstone from the neighbourhood of Bristol. Many rooms show evidence of conflagration in the form of a black deposit, mostly charcoal, above the floor, in which are broken tiles and roof nails. In places three occupation levels can be seen, and sometimes the highest immediately above the burnt deposit is a primitive floor of rough flat stone or irregularly fitted pieces of roof-tile. Series of bronze coins range from Gallienus (A.D. 253-268) to Valens (A.D. 364-378); while the pottery can be ascribed to the second, third and fourth centuries A.D. It is thought that the villa may have been partially destroyed by fire in the raids of Picts, Scots, Franks and Saxons in A.D. 367, when many villas in south and western Britain were abandoned, to be occupied later, when the raiders had been driven out, by lower class Romano-Britons.

\section{Prehistory and the Sahara}

A meeting of the International Commission for Study of the Prehistory of the Sahara, which was initiated by Prof. P. Rivet, and of which Sir Robert 